\title{
PENGARUH KINERJA MANAJERIAL TERHADAP PARTISIPASI PENYUSUNAN ANGGARAN DAN KOMITMEN ORGANISASI PADA LIMA SATUAN KERJA PERANGKAT DAERAH PEMERINTAHAN KOTA KUPANG
}

\author{
Alfred Tandirura Rantelobo ${ }^{1 *}$ \\ $1^{*}$ Politeknik Negeri Kupang \\ "E-mail: alfredrantelobo@yahoo.co.id
}

\begin{abstract}
Abstrak
Penelitian ini bertujuan untuk mengetahui pengaruh langsung partisipasi penyusunan anggaran terhadap kinerja manajerial, komitmen organisasi terhadap kinerja manajerial, partisipasi penyusunan anggaran dan komitmen organisasi terhadap kinerja manajerial secara simultan, dan berapa besar pengaruh partisipasi penyusunan anggaran dan komitmen organisasi terhadap kinerja manajerial. Metode yang digunakan dalam penelitian ini analisis jalur. Sampel dalam penelitian ini didasarkan pada purposive sampling, sampel dari peneltian ini sebanyak 46 orang. Hasil penelitian, yaitu: partisipasi penyusunan anggaran tidak memiliki pengaruh langsung terhadap kinerja manajerial, komitmen organisasi memiliki pengaruh langsung terhadap kinerja manajerial, partisipasi penyusunan anggaran dan komitmen organisasi memiliki pengaruh langsung terhadap kinerja manajerial, dan hasil perhitungan pengaruh langsung partisipasi anggaran terhadap kinerja manajerial sebesar 0,00002 sangat kecil sehingga pengaruh langsung partisipasi penyusunan anggaran terhadap kinerja manajerial tidak ada dan hasil perhitungan pengaruh langsung komitmen organisasi terhadap kinerja manajerial sebesar 0,2079 sedikit besar sehingga ada pengaruh langsung komitmen organisasi terhadap kinerja manajerial.
\end{abstract}

Kata kunci: partisipasi penyusunan anggaran, komitmen organisasi, dan kinerja manajerial

\section{PENDAHULUAN}

Anggaran merupakan rencana keuangan yang dibuat secara rinci dan sistematis yang memuat rencana penerimaan dan rencana pengeluaran. Anggaran adalah rencana keuangan di masa mendatang dan merupakan alat bantu dalam mengkoordinasikan dan mengimplementasikan rencana yang telah dibuat. Dalam sebuah organisasi anggaran memegang peran yang sangat penting karena anggaran mengarahkan penggunaan sumberdaya yang dimiliki organisasi dalam rangka mencapai tujuan organisasi yang telah ditetapkan.

Penyusunan anggaran merupakan suatu proses yang berbeda antara sektor swasta dengan sektor pemerintah, termasuk diantaranya pemerintah daerah. Pada sektor swasta, anggaran merupakan bagian dari rahasia perusahaan yang tertutup untuk publik, namun sebaliknya pada sector pemerintahan atau publik anggaran justru harus diinformasikan kepada public untuk dikritik dan didiskusikan dengan tujuan untuk mendapatkan masukan. Anggaran sektor publik merupakan instrumen akuntabilitas atas pengelolaan dana publik dan pelaksanaan program-program yang dibiayai dari uang publik (Mardiasmo, 2002). Anggaran digunakan sebagai pedoman kerja sehingga proses penyusunan anggaran harus baik, pendekatan yang tepat, serta model-model perhitungan besaran anggaran yang mampu meningkatkan kinerja pada seluruh jajaran manajemen dalam organisasi.

Penyusunan anggaran dapat dilakukan dengan beberapa pendekatan yaitu top-down, bottom up dan pendekatan partisipasi. Dalam sistem penganggaran top-down, dimana rencana dan jumlah anggaran telah ditetapkan oleh atasan/pemegang kuasa pengguna anggaran sehingga bawahan/pelaksana anggaran hanya melakukan apa yang telah ditetapkan oleh anggaran tersebut. Penerapan sistem ini mengakibatkan kinerja bawahan/pelaksana anggaran menjadi tidak efektif karena target yang diberikan terlalu menuntut namun sumber daya yang diberikan 
tidak mencukupi (overloaded). Atasan/pemegang kuasa anggaran kurang mengetahui potensi dan hambatan yang dimiliki oleh bawahan/pelaksana anggaran sehingga memberikan target yang sangat menuntut dibandingkan dengan kemampuan bawahan/pelaksana anggaran. Oleh karena itu, organisasi mulai menerapkan sistem penganggaran yang dapat menanggulangi masalah di atas yakni sistem penganggaran partisipatif (participative budgeting). Melalui sistem ini, bawahan/pelaksana anggaran dilibatkan dalam penyusunan anggaran yang menyangkut bagian dan sub bagiannya sehingga tercapai kesepakatan antara atasan/pemegang kuasa anggaran dan bawahan/pelaksana mengenai anggaran tersebut.

Partisipasi anggaran adalah proses yang menggambarkan individu-individu yang terlibat dalam penyusunan anggaran dan mempunyai pengaruh terhadap target anggaran. Partisipasi penyusunan anggaran merupakan pendekatan yang secara umum dapat meningkatkan kinerja yang pada akhirnya dapat meningkatkan efektivitas organisasi. Penyusunan anggaran secara partisipatif diharapkan dapat meningkatkan kinerja manajer, yaitu ketika suatu tujuan dirancang dan secara partisipasi disetujui maka karyawan akan menginternalisasikan tujuan yang ditetapkan dan memiliki rasa tanggung jawab pribadi untuk mencapainya, karena mereka ikut terlibat dalam penyusunan anggaran. Adanya partisipasi anggaran, akan meningkatkan tanggungjawab serta kinerja dari manajer level bawah dan menengah. Manajer dapat menyampaikan ide-ide kreatif yang dimilikinya kepada manajer atas, yang mana ide tersebut mempunyai tujuan untuk mencapai tujuan perusahaan. Dari adanya keikut sertaaan para manajer level menengah dan bawah dalam penentuan anggaran, maka akan didapatkan keputusan yang lebih realistis sehingga tercipta kesesuaian tujuan organisasi yang lebih besar.

Komitmen organisasi menunjukkan adanya suatu daya dari seseorang dalam mengidentifikasikan keterlibatannya dalam suatu bagian organisasi. Komitmen organisasi dibangun atas dasar kepercayaan pekerja atas nilai-nilai organisasi, kerelaan pekerja membantu mewujudkan tujuan organisasi dan loyalitas untuk tetap menjadi anggota organisasi. Oleh karena itu, komitmen organisasi akan menimbulkan rasa ikut memiliki (sense of belonging) bagi pekerja terhadap organisasi. Jika pekerja merasa jiwanya terikat dengan nila-inilai organisasional yang ada maka dia akan merasa senang dalam bekerja, sehingga kinerjanya dapat meningkat dan secara tidak langsung dapat juga meningkatkan kinerja manajerial.

Kinerja manajerial adalah hasil kerja yang dapat dicapai oleh seseorang atau sekelompok orang dalam suatu organisasi, sesuai dengan wewenang dan tanggungjawab masing-masing dalam rangka mencapai tujuan organisasi. Kinerja manajerial diartikan sebagai kinerja individu dalam kegiatan manajerial yang meliputi perencanaan, investigasi, koordinasi, evaluasi, pengawasan, kepegawaian, negosiasi, perwakilan. Kinerja manajerial menunjukkan kemampuan dan prestasi seorang manajer dalam menjalankan organisasi untuk mewujudkan tujuan yang mengarah kepada tercapainya pelayanan publik. Kinerja manajerial dikatakan efektif jika tujuan anggaran dapat tercapai dan bawahan mendapatkan kesempatan terlibat atau berpartisipasi dalam penganggaran.

Penelitian mengenai pertisipasi penyusunan anggaran terhadap kinerja manajerial telah dilakukan oleh beberapa peneliti sebelumnya. Penelitian yang dilakukan oleh Muharrom (2014) dengan judul tentang Pengaruh Partisipasi Anggaran Terhadap Kinerja Manajerial dengan Komitmen Organisasi dan Persepsi Inovasi sebagai Variabel Intervening pada Direktorat Jenderal Perbendaharaan; kemudian penelitian yang dilakukan oleh Nurcahyani (2010) tentang Pengaruh Partisipasi Anggaran terhadap Kinerja Manajerial melalui Komitmen Organisasi dan Persepsi Inovasi sebagai Variabel Intervening pada Satuan Kerja Perangkat Daerah Kabupaten Magelang; dan penelitian yang dilakukan oleh Utami (2012) tentang Pengaruh Pertisiasi Penyusunan Anggaran terhadap Kinerja Manajerial dengan Komitmen Organisasi sebagai Variabel Moderasi di empat cabang Hotel Santika.

Penelitian ini pada dasarnya merupakan replikasi dari penelitian yang dilakukan oleh Lando (2016). Perbedaan penelitian ini dengan penelitiannya yaitu metode analisis. Penelitian ini menggunakan analisis jalur, sedangkan penelitiannya menggunakan analisis regresi. Persamaan penelitiannya pada objek penelitian di Satuan Kerja Perangkat Daerah Kota Kupang di Dinas Kesehatan, Dinas Pedidikan, Dinas Pendapatan Daerah, Dinas Kependudukan dan Pencatatan Sipil dan Dinas Kelautan dan Perikanan. Hasil penelitiannya menyatakan partisipasi penyusunan anggaran tidak berpengaruh terhadap kinerja manajerial dan komitmen organisasi berpengaruh terhadap kinerja manajerial. 
Anggaran yang dihasilkan merupakan sebagian hasil dari partisipasi setiap elemen organisasi dalam penyusunan anggaran, komitmen organisasi dan kinerja manajerial. Anggaran yang baik, jika dalam pelaksanaannya tidak mengalami kendala dan sesuai dengan apa yang dianggarkan. Telah banyak penelitian yang berhubungan dengan partispasi angaran dan kinerja manajerial. Seperti penelitian yang dilakukan oleh Muharrom (2014) dengan judul Pengaruh Partisipasi Anggaran Terhadap Kinerja Manajerial dengan Komitmen Organisasi dan Persepsi Inovasi sebagai Variabel Intervening pada Direktorat Jenderal Perbendaharaan. Hasil penelitian ini menunjukkan adanya pengaruh langsung partisipasi anggaran terhadap kinerja manajerial. Partisipasi anggaran juga berpengaruh secara signifikan terhadap komitmen organisasi dan persepsi inovasi. Namun, partisipasi anggaran tidak berpengaruh secara tidak langsung terhadap kinerja manajerial melalui variabel intervening komitmen organisasi dan persepsi inovasi.

Nurcahyani (2010), melakukan penelitian untuk menganalisis pengaruh partisipasi anggaran terhadap kinerja manajerial melalui variable intervening yaitu komitmen organisasi dan persepsi inovasi. Responden yang terlibat adalah para pejabat struktural Satuan Kerja Perangkat Daerah (SKPD) di Kabupaten Magelang. Dari total jumlah 160 kuesioner yang disampaikan, sebanyak 124 kuesioner diterima kembali dan hanya 58 kuesioner yang diisi lengkap dan dapat digunakan dalam analisis jalur (path analysis). Hasil penelitian ini menunjukkan adanya pengaruh langsung partisipasi anggaran terhadap kinerja manajerial, Partisipasi anggaran juga berpengaruh secara signifikan terhadap komitmen organisasi dan persepsi inovasi. Namun, partisipasi anggaran tidak berpengaruh secara tidak langsung terhadap kinerja manajerial melalui variabel intervening komitmen organisasi dan persepsi inovasi.

Utami (2012) melakukan penelitian tentang Pengaruh Pertisiasi Penyusunan Anggaran terhadap Kinerja Manajerial dengan Komitmen Organisasi sebagai Variabel Moderasi di empat cabang Hotel Santika. Jenis penelitian ini adalah studi kasus. Hasil penelitian ini menyatakan bahwa adanya pengaruh positif antara partisipasi penyusunan anggaran terhadap kinerja manajerial (hipotesis 1 diterima) dan komitmen organisasi dapat memoderasi pengaruh antara pertisipasi penyusunan anggaran terhadap kinerja manajerial (hipotesis 2 diterima).

Lando (2016) melakukan penelitian tentang Pengaruh Partisipasi Penyusunan Anggaran dan Komitmen Organisasi terhadap Kinerja Manajerial pada Lima Satuan Kerja Perangkat Daerah Kota Kupang. Hasil penelitiannya menyatakan partisipasi penyusunan anggaran tidak berpengaruh terhadap kinerja manajerial dan komitmen organisasi berpengaruh terhadap kinerja manajerial dan partisipasi penyusunan anggaran dan komitmen organisasi berpengaruh terhadap kinerja manajerial secara simultan

Tujuan organisasi akan tercapai jika anggaran yang dihasilkan dilaksanakan semuanya, yang berarti partisipasi penyusunan anggaran, komitmen organisasi dan kinerja manajerial sangat dibutuhkan dalam organisasi. Penelitian ini bertujuan untuk mengetahui pengaruh langsung partisipasi penyusunan anggaran $\left(X_{1}\right)$ dan variable komitmen organisasi $\left(X_{2}\right)$ terhadap variable kinerja manajerial $\left(Y_{1}\right)$ dengan menggunakan analisis jalur.

\section{METODE PENELITIAN}

Lokasi penelitian di 5 (lima) Satuan Kerja Perangkat Daerah yang berada di Kota Kupang yaitu, Dinas Kesehatan, Dinas Pendidikan, Dinas Pendapatan, Dinas Kelautan, dan Dinas Kependudukan. Penelitian ini dilaksanakan pada bulan Juni sampai Juli tahun 2016. Populasi dalam penelitian ini adalah sebanyak 391 yang terdiri dari 5 (lima) Satuan Kerja Perangkat Daerah yang berada di Kota Kupang yaitu, Dinas Kesehatan sebanyak 72 orang, Dinas Pendidikan sebanyak 79 orang, Dinas Pendapatan ssebanyak 118 orang, Dinas Kelautan sebanyak 55 orang, dan Dinas Kependudukan sebanyak 67. Pemilihan dinas dalam penelitian ini karena ke lima SKPD ini termasuk dalam organisasi sektor publik yang dalam penyusunan anggaran dengan menggunakan pendekatan partisipasi.

Pemilihan sampel dalam penelitian ini didasarkan pada purposive sampling. Sampel dipilih berdasarkan kriteria tertentu sehingga dapat mendukung penelitian ini. Sampel dalam penelitian ini adalah pejabat struktural di Satuan Kerja Perangkat Daerah (sekretaris dinas, kepala sub bagian, kepala bidang dan kepala seksi) yang berpartisipasi dalam proses penyusunan RKA-SKPD dan memiliki masa kerja minimal lima tahun dalam periode penyusunan anggaran. Berdasarkan kriteria tersebut di atas sampel dari peneltian ini sebanyak 10 orang dari Dinas Kesehatan, 10 orang dari Dinas Pendidikan, 10 orang dari 
Dinas Pendapatan 8 orang dari Dinas Kependudukan dan 8 orang dari Dinas Kelautan. Jadi jumlah seluruh sampel dalam penelitian ini adalah 46 orang.

Sumber data yang akan penulis gunakan dalam penelitian ini adalah data primer. Data primer merupakan data utama yang akan penulis gunakan dalam menyelesaikan penelitian ini, yang diperoleh secara langsung dari sumber asli (tidak melalui perantara). Dalam hal ini data diperoleh langsung dengan membagi kuesioner kepada pegawai yang berpartisipasi dalam penyusunan anggaran.

Analisis jalur (Path Analysis) untuk mengetahui pengaruh antara variable eksogen dan variable endogen berdasarkan struktur model. Penelitian ini menggambarkan pola hubungan yang mengungkapkan pengaruh seperangkat variable terhadap variable lainnya. Pola hubungan yang semacam ini dapat dianalisis dengan path analysi. Pardede dan Manurung (2014) langkah-langkah analisis jalur, Merancang Model Diagram Jalur dengan membuat Kerangka pemikiran penelitian untuk mengembangkan hipotesis dapat ditunjukkan dalam suatu hubungan konseptual hubungan antar variable. Gambar dibawah merupakan model diagram jalur dengan rancangan hipotesis penelitian sebagai berikut

\section{Gambar 1. Model Diagram Jalur Penelitian}

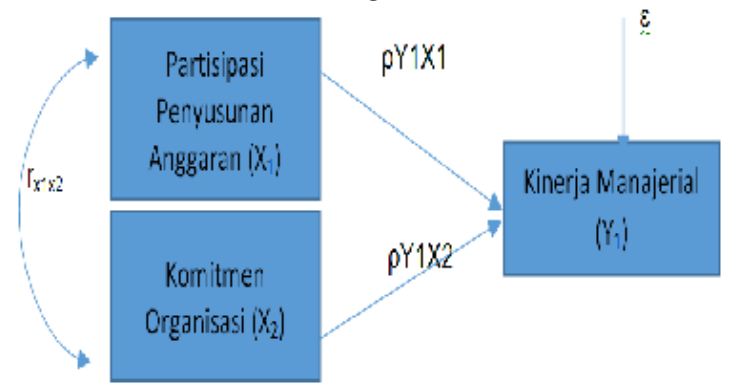

Langkah berikut dengan menentukan Model Persamaan Struktur Sesuai dengan kerangka pemikiran dan pengajuan hipotesis maka dalam merancang model dalam bentuk persamaan. Model dalam bentuk persamaan untuk menguji hipotesis yang disusun dalam penelitian ini merupakan persamaan regresi. Bentuk persamaan regresi yaitu :

$$
Y_{1}=\beta Y_{1} X_{1}+\beta Y_{1} X_{2}+e
$$

Dimana :

$$
\begin{aligned}
Y_{1} & =\text { Komitmen Organisasi } \\
X_{2} & =\text { Kinerja Manajerial } \\
X_{1} & =\text { Partisipasi Penyusunan Anggaran } \\
e & =\text { error }
\end{aligned}
$$

\begin{tabular}{|c|c|c|c|c|}
\hline Model & $\mathrm{R}$ & R Square & $\begin{array}{l}\text { Adjusted R } \\
\text { Square }\end{array}$ & $\begin{array}{l}\text { Std. Error of } \\
\text { the Estimate }\end{array}$ \\
\hline 1 & $.458^{a}$ & .210 & .173 & 1.53325 \\
\hline
\end{tabular}

\section{HASIL DAN PEMBAHASAN}

Hasil analisis regresi diperlihatkan pada table-tabel, sebagai berikut :

Berdasarkan Tabel 1 di atas, besarnya angka $R$-square $\left(R^{2}\right)$ adalah 0,210 , berarti bahwa pengaruh komitmen organisasi dan partisipasi penyusunan anggaran secara simultan terhadap kinerja manajerial adalah $21 \%$. Adapun sisanya $79 \%$ dipengaruhi oleh faktor lain di luar model ini.

Tabel 2. ANOVA ${ }^{\mathrm{D}}$

\begin{tabular}{|l|r|r|r|r|l|}
\hline Model & \multicolumn{1}{|c|}{$\begin{array}{c}\text { Sum of } \\
\text { Squares }\end{array}$} & df & $\begin{array}{r}\text { Mean } \\
\text { Square }\end{array}$ & F & Sig. \\
\hline 1 Regression & 26.848 & 2 & 13.424 & 5.710 & $.006^{a}$ \\
Residual & 101.087 & 43 & 2.351 & & \\
$\quad$ Total & 127.935 & 45 & & & \\
\hline
\end{tabular}

a. Predictors: (Constant), Komitmen, Partisipasi

b. Dependent Variable: Kinerja

Tabel 3. Coefficients ${ }^{a}$

\begin{tabular}{|r|r|r|r|r|}
\hline \multicolumn{2}{|c|}{$\begin{array}{c}\text { Unstandardized } \\
\text { Coefficients }\end{array}$} & $\begin{array}{c}\text { Standardized } \\
\text { Coefficients }\end{array}$ & & \\
\cline { 1 - 3 } $\mathrm{B}$ & Std. Error & \multicolumn{1}{|c|}{ Beta } & \multicolumn{1}{c|}{$\mathrm{t}$} & \multicolumn{1}{c|}{ Sig. } \\
\hline 10.500 & 2.582 & & 4.067 & .000 \\
.003 & .117 & .004 & .030 & .977 \\
.197 & .063 & .456 & 3.129 & .003 \\
\hline
\end{tabular}

a. Dependent Variable: Kinerja

Hasil analisis korelasi diperlihatkan pada table, sebagai berikut :

Tabel 4. Correlations

\begin{tabular}{|ll|r|r|}
\hline & & Partisipasi & Komitmen \\
\hline Partisipasi & Pearson & 1 & .370 \\
& Correlation & & \\
& Sig. (2-tailed) & & .011 \\
$\mathrm{~N}$ & 46 & 46 \\
\hline Komitmen & Pearson & .370 & 1 \\
& Correlation & & \\
& Sig. (2-tailed) & .011 & \\
$\mathrm{~N}$ & 46 & 46 \\
\hline
\end{tabular}

Berdasarkan Tabel 4. Correlations, korelasi antara partisipasi penyusunan anggaran dan komitmen organisasi sebesar 0,370 , berarti hubungan antara variable partisipasi penyusunan anggaran dan komitmen organisasi adalah lemah, searah 
dan signifikan $(0,011<0,05)$.

Berdasarkan Tabel 3 pada kolom Standardized Coefficients yaitu nilai Beta, maka persamaan strukturnya adalah untuk koefisien $\mathrm{X} 1=0,004$ dan koefisien $\mathrm{X} 2=0,456$, sedangkan koefisien $\varepsilon$ :

$$
\varepsilon=\sqrt{(1-0,210}=0,889
$$

Ket : 0,210 hasil $R$-Square pada Tabel 1 .

Sehingga persamaannya adalah :

$$
Y=0.004 X_{1}+0,456 X_{2}+0,889
$$

Perhitungan pengaruh langsung $X 1$

$$
\begin{aligned}
& =(\rho Y 1 X 1)^{*}(\rho Y 1 X 1)=(0,004)^{*}(0,004) \\
& =0,00002
\end{aligned}
$$

Pengaruh melalui hubungan korelasi dengan $\mathrm{X} 2$

$$
\begin{aligned}
& =(\rho Y 1 X 1)^{*}\left(r_{x 1 \times 2}\right)^{*}(\rho Y 1 X 2) \\
& =(0,004)^{*}(0,370)^{*}(0,456)=0,00067
\end{aligned}
$$

Pengaruh $X 1$ ke $Y 1$ secara total

$$
=0,00002+0,00067=0,00069
$$

$$
\begin{aligned}
& \text { Pengaruh langsung X2 } \\
& \quad=(\rho Y 1 X 2)^{*}(\rho Y 1 X 2)=(0,456)^{*}(0,0456) \\
& =0,2079
\end{aligned}
$$

Pengaruh melalui hubungan korelasi dengan $\mathrm{X} 1$

$$
\begin{aligned}
& =(\rho Y 1 X 1)^{*}\left(r_{x 1 \times 2}\right)^{*}(\rho Y 1 X 2) \\
& =(0,004)^{*}(0,370)^{*}(0,456)=0,00067
\end{aligned}
$$

$$
\begin{aligned}
& \text { Pengaruh } \mathrm{X} 2 \text { ke } \mathrm{Y} 1 \text { secara total } \\
& =0,2079+0,00067=0,20857 \\
& \text { Ket } r_{\times 1 \times 2}=0,370 \text { hasil korelasi pada Tabel } \\
& \text { correlation }
\end{aligned}
$$

Jadi penjumlahan pengaruh total, yaitu $0,00069+0,20857=0,210$ adalah nilai $R$ Square pada Tabel 1.

Berdasarkan hasil pada Tabel 2 di atas, nilai sign $=0,006$, berarti $<0,05$ maka $\mathrm{Ha}$ diterima, yang berarti Ada pengaruh langsung partisipasi penyusunan anggaran dan komitmen organisasi terhadap kinerja manajerial secara simultan sebesar 0,21 . Hasil ini sama dengan penelitian Londo (2016) yang menunjukkan bahwa partisipasi penyusunan anggaran dan komitmen organisasi memberikan pengaruh yang lebih baik terhadap kinerja manjerial, walaupun bagian kinerja manajerial hanya pada bagian kordinasi, evaluasi, pengawasan dan pengaturan staf.

Kinerja manajerial akan baik jika dalam penyusunan anggaran pada Dinas Kesehatan, Dinas Pendidikan, Dinas Pendapatan, Dinas Kelautan, dan Dinas Kependudukan melibatkan pegawai untuk berpartisipasi dalam menyusun anggaran serta para pegawai mempunyai komitmen untuk berkerja mencapai tujuan pada dinas tersebut.

Jadi keterlibatan pegawai dalam penyusunan anggaran dan adanya komitmen organisasi para pegawai akan menberikan dampak yang baik bagi kinerja manajerial. Untuk mendapatkan hasil kinerja manajerial yang maksimal, maka bagian perencanaan, investasi, negosiasi dan perwakilan ditambahkan.

Nilai sign variabel partisipasi penyusunan anggaran $=0,977$, berarti $>0,05$ maka Ho diterima yang berarti tidak ada pengaruh langsung partisipasi penyusunan anggaran terhadap kinerja manajerial, hasil ini sama dengan penelitian Londo (2016). Ini menunjukkan bahwa partisipasi pegawai dalam penyusunan anggaran tidak memberikan peningkatan kinerja manajerial yang lebih baik pada Dinas Kesehatan, Dinas Pendidikan, Dinas Pendapatan, Dinas Kelautan dan Dinas Kependudukan yang diakibatkan kerena kinerja manajerial pada bagian perencanaan, investigasi, negosiasi dan perwakilan tidak maksimal.

Jadi bagian perencanaan dalam proses menentukan tujuan, sasaran, kebijakan dan tindakan; bagian investigasi dalam mengumpulkan dan menyiapkan informasi biasanya dalam bentuk laporan, catatan dan rekening; bagian negosiasi dalam mengumpulkan dan menyiapkan informasi biasanya dalam bentuk laporan, catatan dan rekening dan bagian perwakilan dalam menyampaikan informasi tentang visi, misi, dan kegiatan-kegiatan organisasi dengan cara pidato, konsultasi dan sosialisasi kepada pihak luar organisasi mempengaruhi kinerja manajerial terhadap partisipasi penyusunan anggaran.

Bagian kinerja manajerial tentang kordinasi, evaluasi, pengawasan dan pengaturan staf belum bisa memberikan pengaruh kinerja manajerial terhadap partisipasi penyusunan anggaran. Supaya kinerja manajerial berpengaruh terhadap partisipasi penyusunan anggaran, maka bagian kinerja manajerial yaitu perencanaan, investasi, negosiasi dan perwalikan harus ditambahkan sehingga ada pengaruh partisipasi penyusunan anggaran terhadap kinerja manjerial. 
Nilai sign komitmen organisasi $=0,003$, berarti $<0,05$ maka Ha diterima yang berarti ada pengaruh langsung komitmen organisasi terhadap kinerja manajerial, sehingga mendukung penelitian Londo (2016). Hal Ini menunjukkan bahwa komitmen organisasi memberikan peningkatan kinerja manajerial yang lebih baik, walaupun bagian kiinerja manajerial hanya bagian kordinasi, evaluasi, pengawasan dan pengaturan staf bisa mempengaruhi partisipasi penyusunan anggaran dan komitmen organisasi. Kinerja manajerial akan baik jika komitmen organisasi pada Dinas Kesehatan, Dinas Pendidikan, Dinas Pendapatan, Dinas Kelautan, dan Dinas Kependudukan para pegawainya mempunyai komitmen untuk berkerja mencapai tujuan pada dinas tersebut.

Jadi komitmen organisasi para pegawai akan menberikan dampak yang baik bagi kinerja manajerial. Untuk mendapatkan hasil kinerja manajerial yang maksimal, maka bagian perencanaan, investasi, negosiasi dan perwakilan ditambahkan.

Hasil perhitungan pengaruh langsung partisipasi anggaran terhadap kinerja manajerial sebesar 0,00002 sangat kecil sehingga pengaruh langsung partisipasi penyusunan anggaran terhadap kinerja manajerial tidak ada, ini sesuai dengan hasil hipotesis.

Hasil perhitungan pengaruh partisipasi penyusunan anggaran melalui hubungan korelasi dengan komitmen orgnisasi adalah 0,00067 . Jadi pengaruh total partisipasi anggaran ke kinerja manajerial adalah $0,00002+0,00067=0,00069$. Hasil ini sangat kecil dan mendukung hasil hipotesis.

Hasil perhitungan pengaruh langsung komitmen organisasi terhadap kinerja manajerial sebesar 0,2079 sedikit besar sehingga ada pengaruh langsung komitmen organisasi terhadap kinerja manajerial, ini sesuai dengan hasil hipotesis.

Hasil perhitungan pengaruh komitmen organisasi melalui hubungan korelasi dengan partisipasi penyusunan anggaran adalah 0,00067 . Jadi pengaruh total partisipasi anggaran ke kinerja manajerial adalah 0,2079 $+0,00067=0,20857$. Hasil ini sedikit besar dan mendukung hasil hipotesis.

\section{PENUTUP}

Berdasarkan hasil penelitian, dapat disimpulkan bahwa ternyata terdapat pengaruh langsung yang relatif kecil dan tidak signifikan antara variabel partisipasi penyusunan anggaran terhadap kinerja manajerial yaitu sebesar 0,004 . Hal ini berarti bahwa setiap pejabat strutural yang terlibat dalam partisipasi anggaran seperti sekretaris dinas, kepala sub bagian dan kepala bidang serta kepala seksi yang terlibat dan memiliki tingkat partisipasi penyusunan RKA-SKPD yang tinggi tetapi keterlibatan dan memiliki tingkat partisipasi yang tinggi belum cukup untuk dapat meningkatkan kinerja manajerianya.

Pengaruh langsung variabel komitmen organisasi terhadap kinerja manajerial sebesar 0,456 yang berarti bahwa komitmen organisasi memiliki pengaruh terhadap kinerja manajerial. Hasil penelitian ini menunjukan komitmen organisasi berpengaruh signifikan terhadap kinerja manajerial yang berarti bahwa sekretaris dinas, kepala sub bagian dan kepala bidang mempunyai komitmen yang tinggi terhadap organisasinya. Semakin tinggi komitmen pegawai terhadap organisasinya maka semakin tinggi pula tingkat kinerjanya.

Pengaruh langsung variabel partisipasi penyusunan anggaran dan komitmen organisasi terhadap kinerja manajerial secara simultan sebesar 0,21. Partisipasi penyusunan anggaran dan komitmen organisasi memiliki pengaruh terhadap kinerja manajerial. Hasil penelitian ini menunjukan partisipasi penyusunan anggaran dan komitmen organisasi secara bersama-sama berpengaruh signifikan terhadap kinerja manajerial. Hal ini berarti bahwa semakin tinggi tingkat keterlibatan pegawai dalam proses penyusunan anggaran serta semakin tinggi komitmen pegawai terhadap organisasinya, maka akan dapat meningkatkan kinerja manajerial.

Hasil perhitungan pengaruh langsung partisipasi anggaran terhadap kinerja manajerial sebesar 0,00002 sangat kecil sehingga pengaruh langsung partisipasi penyusunan anggaran terhadap kinerja manajerial tidak ada dan hasil perhitungan pengaruh langsung komitmen organisasi terhadap kinerja manajerial sebesar 0,2079 sedikit besar sehingga ada pengaruh langsung komitmen organisasi terhadap kinerja manajerial.

Dengan demikian setiap SKPD dalam penelitian ini, sebaiknya mengoptimalkan penerapan anggaran partisipatif bukan hanya sekedar partisipasi semu karena hal ini berdampak pada meningkatnya kinerja manajerial, dan juga melakukan pengawasan dan evaluasi berkala terhadap tugas pokok dan fungsi agar meningkatkan komitmen pegawai terhadap organisasi.

SKPD juga perlu memberikan kesempatan kepada pegawai untuk melakukan inovasi dalam menjalankan tugas dan fungsinya tanpa melanggar peraturan dan ketetapan yang 
berlaku. Pegawai dengan inovasi yang tinggi akan memiliki implikasi terhadap peningkatan kinerja mereka.

\section{DAFTAR PUSTAKA}

Bastian, Indra. 2010. "Akuntansi Sektor Publik: Suatu Pengantar". Jakarta: Erlangga.

Dasatra, Z. Y. (2011) Analisis hubungan antara Anggaran Partisipatif dengan Kinerja Manajerial melalui Evaluasi dan Kompensasi sebagai Variabel Moderating dan Motivasi sebagai Variabel Intervening (Studi Empiris pada PT. Kereta Api Indonesia DAOP IX Jember), Skripsi. Jember: Fakultas Ekonomi Universitas Jember.

Lando (2016) Pengaruh Partisipasi Penyusunan Anggaran dan Komitmen Organisasi terhadap Kinerja Manajerial pada Lima Satuan Kerja Perangkat Daerah Kota Kupang, Skripsi, Program Studi Akuntansi Sektor Publik Politeknik Negeri Kupang

Mardiasmo (2002) Akuntansi Sektor Publik, Yogyakarta: Andi Offset.

Muharrom, F. L, (2014) Pengaruh Partisipasi Anggaran terhadap Kinerja Manajerial dengan Komitmen Organisasi dan Persepsi Inovasi sebagai Variabel Intervening pada Direktorat Jenderal Perbendaharaan, Skripsi. Semarang: Fakultas Ekonomi dan Bisnis Universitas Diponegoro.

Nurcahyani, K. (2010) Pengaruh Partisipasi Anggaran terhadap Kinerja Manajerial melalui Komitmen Organisasi dan Persepsi Inovasi sebagai Variabel Intervening (Studi Kasus pada Pejabat struktural SKPD Pemerintah Kabupaten Magelang), Skripsi. Semarang: Fakultas Ekonomi Universitas Diponegoro.

Pardede, Manurung (2014) Analisis Jalur (Path Anaalysis) Teori dan Aplikasi dalam Riset Bisnis. Jakarta. Rineka Cipta.

Peraturan Pemerintah Menteri Nomor 58 Tahun 2005 Tentang Pengelolaan Keuangan Daerah.

Simanjuntak, Payaman J. (2005) Manajemen dan Evaluasi Kinerja. Jakarta: Lembaga Penerbir Fakultas Ekonomi Universia Indonesia.

\begin{abstract}
Utami, Laurensia K. R. (2016) Pengaruh Parisipasi Penyusunan Anggaran terhadap Kinerja Manajerial dengan Komitmen Organisasi sebagai Variabel Moderating (Studi Kasus di Empat Cabang Hotel Santika), Skripsi. Yogyakarta, Fakultas Ekonomi Universitas Sanata Dharma.
\end{abstract}

